\title{
A Convict Criminology Perspective on Sex Offender Laws: America's "War against Sex Offenders"
}

Brian E. Oliver

\section{INTRODUCTION}

Over the past twenty years there has been a shift in the 'tough on crime' movement within the United States. While the 'war on drugs' began in the 1970s, in the 1990s America found a new 'enemy' to fight - the sex offender. In 2006, former President George W. Bush signed the Adam Walsh Act into law, escalating the war waged against sex offenders.

My name is Brian Oliver and I have just completed a PhD in Criminology and Criminal Justice at the University of Missouri - St. Louis. I am also a convicted sex offender, having served six years and three months in prison in the 1990s for non-violent sex offenses committed against minors while I was an adolescent and young adult. I have experienced firsthand the effects of America's punitive war towards those who have committed sexual crimes. This war has branded virtually every sex offender as a potential monster - a sociopath capable of kidnapping, raping, and murdering innocent women and children.

America's war against sex offenders shows little compassion for those people who have been convicted of a sex offense. As a result, many sex offenders experience a shortage of housing options, as well as additional isolation from employment opportunities, social support, social services and mental health treatment (Levenson, 2005). The number of sex offenders who find themselves homeless has increased dramatically in some places as a result of this war (Loving et al., 2008). This war has not only affected those with sex offense convictions, but also has had destructive consequences for non-offending family members (Levenson and Tewksbury, 2009; Tewksbury and Levenson, 2009). In spite of these negative consequences, the war is raging and has only intensified in recent years.

This article will discuss the effects of this war. The first section will begin with a discussion of why America's war against sex offenders is misguided. The second section will show how 'tough' sex offender laws are harsher than other 'tough on crime' laws. The third section will review research findings relating to the effect of these laws and will discuss why the research indicates that these measures do not make American society safer. The fourth section will detail specific reasons why America's war against sex offenders actually does more harm than good. In the fifth 
section, specific attention will be given to the sex offender registry and how its very existence is punitive in nature. The sixth section will give a Convict Criminology (CC) Perspective, whereby it will be argued that America's war against sex offenders needs to end and that sex offenders need to stop being treated more harshly than other forms of criminal offenders. The seventh, and concluding section will argue that, instead of having laws in place which restrict where sex offenders can live, work, and travel, and require them to register with police for the remainder of their lives, the day sex offenders complete their full sentence is the day their punishment should end.

\section{WHY AMERICA'S WAR AGAINST SEX OFFENDERS IS MISGUIDED}

What is so tragic about America's war against sex offenders is that it runs counter to the findings of numerous, well-designed research studies that indicate that convicted sex offenders are not more dangerous than other classes of persons convicted of crime (Richards and Ross, 2003). For instance, two large, multi-state studies conducted by the Bureau of Justice Statistics found that convicted sex offenders who served time in prison had lower re-arrest rates than almost any other type of offender (Beck and Shipley, 1989; Langan and Levin, 2002). Several studies have found that most convicted sex offenders do not go on to commit new sex crimes (Bureau of Justice Statistics, 2003; Hanson and Morton-Bourgon, 2004, 2005; Harris and Hanson, 2004). In another study, Sandler et al. (2008) looked at people arrested for sex offenses in New York between 1986 and 2006 and found only 4.1 percent of arrested rapists and 5.9 percent of arrested child molesters involved repeat sex offenders. A study by Sample (2006) found that sex offenders were less likely to subsequently be arrested on a homicide charge than most other types of offenders.

Despite these fairly consistent findings, which show that convicted sex offenders are not more dangerous than other types of offenders, heavy media coverage following horrific, yet very rare, rapes and murders of women and children by previously convicted sex offenders have left the public with the perception that these individuals are very dangerous and have extremely high sexual recidivism rates (Levenson et al., 2007; Katz-Schiavone et al., 2008). These cases, along with intense lobbying for 'tougher' sex offender 
laws by certain groups whose members include sexual abuse survivors and parents of children who have been murdered in horrific manners, have left both state and federal legislators quite willing to pass a series of increasingly punitive laws limiting the rights of those convicted of sex offenses.

Researchers within the CC movement have made statements that the American criminal justice system provides many obstacles for ex-offenders to succeed once they are released from prison (see Richards and Jones, 1997, 2004; Richards, 2009; Ross et al., 2010; Murphy et al., 2010; Richards et al., 2011) and about the harm caused to individuals who go through the criminal justice system (see Richards and Ross, 2001). However, there has not been much specific discussion about the extra barriers faced by offenders and by academics, like myself, who have been convicted of sexual offenses to date. Moreover, while the works of CC movement authors (Richards and Jones, 1997, 2004; Richards and Ross, 2001) and other scholars (Petersilia, 2003; Travis, 2005) clearly document the damage caused by collateral consequences convicted felons face, what they fail to note, and what this paper will address, is how these punitive laws affect convicted sex offenders more broadly and severely than any other category of convicted persons. Whereas other classes of felony offenders encounter many problems when they attempt to reenter the community, the extra consequences faced by sex offenders make their lives even after their sentences are over similar in many aspects to those who are still on parole. In essence, if you are a convicted sex offender in America, you will end up serving a sentence, complete with multiple restrictions and reporting requirements, for the rest of your life.

\section{HOW SEX OFFENDER LAWS ARE HARSHER THAN OTHER 'TOUGH ON CRIME' LAWS}

America's 'tough on crime' movement has limited the prospects of those with felony records in many ways, including limiting access former prisoners have to employment opportunities, public assistance, education loans, driving privileges, public housing, food stamps and the like (Petersilia, 2003; Travis, 2005). I would argue, however, that the laws are a lot harder and limit the rights of sex offenders much more than any other class of criminal in America. In many ways, sex offenders are viewed by the public and by the politicians they represent as being incurably lost, evil and completely depraved. Thus, while there may have been resistance if an 
attempt had been made to enact such laws for other classes of offenders, many of the sex offender laws currently in place were enacted with virtually no resistance because sex offenders are not viewed as deserving full human rights (Spencer, 2009).

For evidence in support of this proposition, I need to go no further than examining some of the laws currently in effect in states across America. A close look at these laws will show that lawmakers have deliberately and intentionally decided to limit the rights of sex offenders in a variety of fashions that do not affect other types of offenders (Mustaine and Tewksbury, 2011). While many will claim that these laws were put in place in a desire to make the United States a safer place, a closer look at the laws will show that what they actually do is continue to punish sex offenders long after their sentences are over.

Before discussing these restrictions, in light of my earlier statement that sex offenders in America are in essence on a form of lifetime parole, it is noteworthy to point out that many of these laws have also been common conditions of probation or parole for sex offenders for decades. Having conditions while on probation or parole is commonplace in America. What is different about the conditions as they pertain to sex offenders, however, is that laws make many of these conditions exist for the rest of a sex offender's life. These types of laws really do not exist for any other type of offender. While other felons still suffer some limitations once they have completed their parole (e.g. voting, firearms and occupational / professional prohibitions), they no longer have to report to parole authorities or register with law enforcement. This, however, does not hold true for male or female sex offenders.

A brief review of statutes from Missouri and Iowa exemplify some of these laws. Laws in Missouri have been passed in recent years making it illegal for sex offenders to live within 1,000 feet of a school, from being present or loitering within 500 feet of an elementary, middle or high school or licensed day care center (unless sex offender is the parent of a student there), from being present or loitering within 500 feet of a public park or swimming pool, and from participating in activities or being allowed outside their house on Halloween evening. Laws in Iowa include some of these same prohibitions, but also prohibit a sex offender from going to a public library, unless he or she has the written permission of the library administrator, and further prohibits sex offenders from being present on public beaches if a person under eighteen is present at the beach. It is 
again important to point out many of these laws apply to all registered sex offenders, not just those on probation or parole. While state legislators may argue that these laws are necessary to protect society, studies have not found evidence to support this proposition.

\section{WHAT RESEARCH HAS FOUND: WHY THESE LAWS DO NOT MAKE SOCIETY SAFER}

As far as residency restrictions go, for example, studies have not found evidence that limiting where sex offenders can live in proximity to schools enhances public safety. The Minnesota Department of Corrections (2003) examined the cases of 239 high-risk sex offenders living in the state to determine if where they lived in proximity to a school or park was related to the chances that they would commit a new sexual offense. This study reported, "there is no evidence in Minnesota that residential proximity to schools or parks affects reoffense. Thirteen level three offenders released between 1997 and 1999 have been rearrested for a new sex offense since their release from prison, and in none of the cases has residential proximity to schools or parks been a factor in their reoffense" (MDOC, 2003, p. 11). A second study conducted by the Colorado Department of Public Safety (2004) compared the cases of sex offenders who reoffended versus those who did not. This study found that "placing restrictions on the location of correctionally supervised sex offender residences may not deter the sex offender from re-offending and should not be considered as a method to control sexual offending recidivism" (CDPS, 2004, p. 4). A more recent study by Zandbergen et al. (2010) used a matched sample of 165 sexual recidivists and 165 non-recidivists from Florida for the period 2004 to 2006 to investigate if there was a relationship between where a sex offender resided and whether he reoffended. Like the two prior studies, "[t]he results of this study indicate no empirical association between where a sex offender lives and whether he reoffends sexually against a minor [...] Sex offenders who lived in closer proximity to schools and daycares were not more likely to reoffend than those who lived farther away" (p. 498).

Additionally, although there have not been many studies regarding laws that place limits on the activities convicted sex offenders are allowed to participate in, a study by Chaffin et al. (2009) nevertheless cast doubt on the 
benefit of restricting convicted sex offenders from engaging in Halloween activities. What the study found was that such laws had little impact on offending rates because sex offenders were not more likely to reoffend on Halloween than on other dates.

\section{ADDITIONAL REASONS WHY HARSHER SEX OFFENDER LAWS DO MORE HARM THAN GOOD}

Beyond the fact that many of these laws have not been found to increase public safety, there are additional factors that legislators fail to take into consideration in passing these laws. The first is that, although many of these laws were passed with the intent of protecting children, what state lawmakers fail to consider is that many convicted sex offenders later become law abiding parents with very legitimate reasons for engaging in some of these prohibited activities. Regarding the Halloween restriction, there are many convicted sex offenders who are no longer under supervision but who have children and who want the ability to supervise their children while trick or treating on Halloween.

Another legitimate use concerns parks. While sex offenders who have young children would certainly have a legitimate reason to want to appropriately supervise their children's activities at parks when the children are young, especially if they are single parents, another thing that lawmakers have neglected to take into consideration in passing these park restriction laws is that these milieus are also places where exclusively adult activities take place. I used to walk regularly on the walking trail at a park near where I lived. That was a legitimate use and had nothing to do with children. Additionally, from the time I was in my early thirties up until I turned forty, I was actively and regularly involved in church related volleyball. These events were healthy, safe ways for me to get exercise by being involved in sports activities with other adults. A few years back, after the park restriction laws went into effect, I started playing volleyball with a church group that would every once in a while schedule an outdoor volleyball event held at a public park. Even though this event was a legitimate adult activity, I was not permitted to go because of the law making my presence in a park a criminal offense. 
While lawmakers may truly desire to make society safer by prohibiting the activities those formerly convicted of sex offenses engage in, the legal restrictions they have passed have been based on emotion and not scientific fact. What lawmakers fail to consider is that the vast majority of sex offenders are not high-risk offenders. Many are low risk offenders who do not pose a threat to reoffend. As a result, for many convicted sex offenders, these laws end up being little more than continued punishments after their court-imposed sentences are completed.

\section{HOW THE SEX OFFENDER REGISTRY SERVES AS FURTHER PUNISHMENT}

As bad as many of these harsher sex offender laws may be, perhaps the most destructive law passed in America related to this group are sex offender registries. Under these types of law, sex offenders are required to register on a regular basis with the police in the areas where they live, work or go to school. Although specific laws vary from state to state, the law in effect in Missouri in 2011, required sex offenders to register in person with the police between two and four times a year depending on the offense. While the law allowed a few exceptions, for many sex offenders, this was a lifetime requirement. In addition to registering, the Missouri Highway Patrol maintained an Internet based sex offender registry, which allowed anyone access to the following:

(1) The name and any known aliases of the offender; (2) The date of birth and any known alias dates of birth of the offender; (3) A physical description of the offender; (4) The residence, temporary, work, and school addresses of the offender, including the street address, city, county, state, and zip code; (5) Any photographs of the offender; (6) A physical description of the offender's vehicles, including the year, make, model, color, and license plate number; (7) The nature and dates of all offenses qualifying the offender to register; [and] (8) The date on which the offender was released from the department of mental health, prison, or jail, or placed on parole, supervised release, or probation for the offenses qualifying the offender to register" (Missouri Statute 589.402, subsection 3, 2011). 
One problem with sex offender registration is that, similar to the findings of studies that looked at other forms of sex offender specific legislation, there is currently little empirical evidence that such measures have had a significant impact on offender sexual recidivism rates (Fitch, 2006). Schram and Milloy (1995) compared one group of 125 adult sex offenders released in Washington following the implementation of the community notification law against a second group of 90 adult sex offenders released in Washington prior to the implementation of this law. They found that at the end of fifty-four months at risk, the notification group had a slightly lower, yet statistically insignificant, estimated rate of sexual recidivism (19 percent) than the comparison group (22 percent). Adkins et al. (2000) further compared a group of 201 convicted sex offenders in Iowa released from supervision before the registration requirement with 233 convicted sex offenders released immediately following the implementation of this measure. Results showed that registered sex offenders had only slightly lower, yet not statistically significant, rates of recidivism for sexual offenses (3.0 percent versus 3.5 percent).

A second problem with the registry is that research has shown that sex offender registration can lead to counterproductive collateral consequences. Research conducted with 183 registered sex offenders in Florida (Levenson and Cotter, 2005), with 121 registered sex offenders in Kentucky (Tewksbury, 2005), and with 40 female registrants in Indiana and Kentucky (Tewksbury, 2004), indicates that such individuals may experience social stigmatization and incidents of harassment, along with difficulties securing housing and finding or maintaining employment as a result of sex offender registration.

I personally experienced negative collateral consequences as a result of being listed on the Missouri Sex Offender Registry on two separate occasions while in graduate school. The first occurred in May 2007, when the Director of Student Housing at the University of Missouri - St. Louis refused to renew my lease for an on-campus apartment after a student who lived in campus housing with his or her children complained about my presence there. This one student believed that my presence represented a danger to his or her children, even though I had done nothing inappropriate during the two and a half years I had lived in student housing.

The second problem occurred in February 2010, when the interim vice president at a private university where I had been hired as an adjunct lecturer terminated my employment after the parent of one of the adult students in 
the class I was teaching found out that I was registered sex offender and demanded that I not be allowed to continue to teach. My understanding from talking to various sources is that shortly after I began teaching, one of the students in the class found my name through a sex offender registry search and told other students. The word started to spread and eventually some of the students told their parents. Although I had told the department chair that I was a convicted felon when interviewed for the position, this fact did not allow me to keep my job. Instead, the threat of having the parent withdraw both his children from the university and take the story to the press was more than the university was willing to risk.

Once again, individuals meant well, but acted out of emotion and not scientific fact. What the information from the previously mentioned studies, along with the two personal experiences I discuss above where I lost both housing and employment as a result of being listed on the sex offender registry, show is that sex offender registries, in reality, do very little to make society a safer place. They do, however, make successfully reintegrating back into society a lot harder for those men and women who have been convicted of a sex offense.

\section{A CONVICT CRIMINOLOGY PERSPECTIVE ON SEX OFFENDERS}

December 11, 2000, was supposed to be a day of joy and celebration for me. After spending six years and three months in prison, three months in a halfway house and seventeen months on parole, this was the date I successfully discharged my parole. I had completed my sentence. The days of having to regularly check in with my parole officer and being limited in where I could live, work, and hang out were supposed to be over. Or that is what I thought was going to happen that evening as I tore up my parole papers and threw them in the trash dumpster of the apartment complex where I lived.

It turns out that I was wrong. Fast forward to 2011. Although I have not been arrested for any felony or misdemeanor offense since my official discharge from parole, law enforcement still has me living with conditions quite similar to those I was required to live under while on parole. Even though I no longer have to check in with a parole officer every month, the law nevertheless currently requires me to register with the police every three months. From August 28, 2006 - the date the law went into effect - up until February 19, 2008, when 
the Missouri Supreme Court ruled that state residency restrictions could not apply to offenders convicted before the enactment date of the law, I was limited in where I could live. By being prohibited from living within 1,000 feet of an elementary, middle or high school, or day care center in Missouri, I was unable to temporarily move in with family after I was told I had to move out of student housing. This resulted in a frantic search for an alternative place to live. While the residency restriction law no longer affects my residency options in Missouri, I am nevertheless limited in where I can live in a large number of states. To this day, I would further be risking arrest if I travelled to a public park or swimming pool in Missouri, even if I had a legitimate reason for being there.

Such laws should be unconstitutional. When I pled guilty in the 1990s, I was given sentences that were supposed to have definite end dates. I pled guilty understanding that I would be punished for several years. However, I was not given a sentence that required me to register with the police and further placed restrictions on my activities for the remainder of my life. I was not given a life sentence and, as such, it is wrong to effectively give me one after the fact. This is wrong because this is not what I was sentenced to in the 1990s. The fact that I am a convicted sex offender should not matter because none of these laws were in effect when I committed my crimes. Adding additional conditions to my sentence after the fact is, in my opinion, a violation of the ex post facto clause of the Constitution and should not be allowed.

\section{CONCLUSION}

A common CC Perspective on sex offenders is that they should be treated the same as people convicted of non-sexual crimes. They should be given reasonable sentences of community treatment, probation, jail or prison. When the court ordered sentence has been completed it should be over. They should be permitted back into society and provided a fair opportunity to resume their lives in peace. As Dr. Stephen Richards, an ex-convict who served federal prison time on a drug conviction and now a professor of criminal justice, wrote me in an e-mail:

I think all criminal records should be protected by privacy laws, like medical records, as is the case in many European countries. I do not think any person that has completed their sentence of incarceration and parole should have to register or report to police or anybody else, once their sentence is completed. Sex Offender Laws that require registration with 
the police remind me of what the Nazi required of Jews in the 1930-40's.

As a German Jew, I find the way we treat sex offenders in the USA to be a crime, a violation of human rights, and a frightening step towards fascism.

\section{REFERENCES}

Adkins, G., D. Huff and P. Stageberg (2000) The Iowa Sex Offender Registry and Recidivism, Des Moines (IA): Iowa Department of Human Rights.

Beck, A. J. and B. E. Shipley (1989) Recidivism of Prisoners Released in 1983, Washington (D.C.): Bureau of Justice Statistics.

Bureau of Justice Statistics (2003) Recidivism of Sex Offenders Released from Prison in 1994, Washington (D.C.): U.S. Department of Justice.

Chaffin, M., J. S. Levenson, E. J. Letourneau and P. Stern (2009) "How Safe Are Trickor-treaters? An Analysis of Child Sex Crime Rates on Halloween", Sexual Abuse: A Journal of Research and Treatment, 21: 363-374.

Colorado Department of Public Safety (2004) Report on Safety Issues Raised by Living Arrangements for and Location of Sex Offenders in the Community, Denver (CO): Sex Offender Management Board.

Fitch, K. (2006) Megan's Law: Does It Protect Children?, London: NSPCC.

Hanson, R. K. and K. Morton-Bourgon (2005) "The Characteristics of Persistent Sexual Offenders: A Meta-analysis of Recidivism Studies", Journal of Consulting and Clinical Psychology, 73: 1154-1163.

Hanson, R. K. and K. Morton-Bourgon (2004) Predictors of Sexual Recidivism: An Updated Meta-Analysis, Ottawa: Public Works and Government Services.

Harris, A. J. R. and R. K. Hanson (2004) Sex Offender Recidivism: A Simple Question, Ottawa: Solicitor General of Canada.

Katz-Schiavone, S., J. S. Levenson and A. R. Ackerman (2008) "Myths and Facts About Sexual Violence: Public Perceptions and Implication for Prevention", Journal of Criminal Justice and Popular Culture, 15: 291-311.

Langan, P. A. and D. J. Levin (2002) Recidivism of Prisoners Released in 1994, Washington (D.C.): Bureau of Justice Statistics.

Levenson, J. S. (2005) "Sex Offender Residence Restrictions", Sex Offender Law Report, Kingston (NJ): Civil Research Institute.

Levenson, J. S., Y. Brannon, T. Fortney and J. Baker (2007) "Public Perceptions About Sex Offenders and Community Protection Policies", Analyses of Social Issues and Public Policy, 7: 1-25.

Levenson, J. S. and L. P. Cotter (2005) "The Impact of Sex Offender Residence Restrictions: 1,000 Feet From Danger or One Step From Absurd?", International Journal of Offender Therapy and Comparative Criminology, 49: 168-178.

Levenson, J. and R. Tewksbury (2009) "Collateral Damage: Family Members of Registered Sex Offenders", American Journal of Criminal Justice, 34: 54-68.

Loving, R., J. K. Singer and M. Maguire (2008) Homelessness among Registered Sex Offenders in California: The Numbers, the Risks and the Response, Sacramento (CA): California Sex Offender Management Board. 
Minnesota Department of Corrections (2003) Level Three Sex Offenders Residential Placement Issues, St. Paul (MN).

Murphy, D. S., B. Fuleihan, S. C. Richards and R. S. Jones (2010) "The Electronic "Scarlet Letter": Criminal Backgrounding and a Perpetual Spoiled Identity", Journal of Offender Rehabilitation, 50: 101-118.

Mustaine, E. E. and R. Tewksbury (2011) "Residential Relegation of Registered Sex Offenders", American Journal of Criminal Justice, 36: 44-57.

Petersilia, J. (2003) When Prisoners Come Home: Parole and Prisoner Reentry, Oxford (UK): Oxford University Press.

Richards, S. C. (2009). "A Convict Perspective on Community Punishment: Further Lessons From the Darkness of Prison", in J. I. Ross (ed.), Cutting the Edge: Current Perspectives in Radical/Critical Criminology and Criminal Justice (second edition). Edison, NJ: Transaction, pp. 122-144.

Richards, S. C. and R. S. Jones (2004) "Beating the Perpetual Incarceration Machine", in S. Maruna and R. Immarigeon (Eds.), After Crime and Punishment: Pathways to Offender Reintegration, London: Willan Publishers, pp. 201-232.

Richards, S. C. and R. S. Jones (1997) "Perpetual Incarceration Machine: Impediments to Postprison Success", Journal of Contemporary Criminal Justice, 13: 4-19.

Richards, S. C. and J. I. Ross (2003) "Convict Perspective on the Classification of Prisoners", Criminology \& Public Policy, 2: 243-252.

Richards, S. C. and J. I. Ross (2001) "Introducing the New School of Convict Criminology", Social Justice, 28: 177-190.

Richards, S. C., J. I. Ross, G. Newbold, M. Lenza, R. S. Jones, D. S. Murphy and R. S. Grigsby (2011) "Convict Criminology: Prisoner Re-entry Policy Recommendations", in I. O. Ekunwe and R. S. Jones (eds.), Global Perspectives on Re-entry, Tampere (FI): University of Tampere Press, pp. 198-222.

Ross, J. I., S. C. Richards, G. Newbold, R. S. Jones, M. Lenza, D. S. Murphy, R. G. Hogan and G. D. Curry (2010) "Knocking on the Ivory Towers' Door: The Experience of Ex-convicts Applying for Tenure-track University Positions", Journal of Criminal Justice Education, 21: 1-19.

Sandler, J. C., N. J. Freeman and K. M. Socia (2008) "Does a Watched Pot Boil? A Timeseries Analysis of New York State's Sex Offender Registration and Notification Law", Psychology, Public Policy, and Law, 14: 284-302.

Sample, L. L. (2006) "An Examination of the Degree To Which Sex Offenders Kill”, Criminal Justice Review, 31: 230-250.

Schram, D. D. and C. D. Milloy (1995) Community Notification: A Study of Offender Characteristics and Recidivism, Olympia (WA): Washington State Institute for Public Policy.

Spencer, D. (2009) "Sex Offender as Homo Sacer”, Punishment \& Society, 11: 219-240.

Tewksbury, R. (2005) “Collateral Consequences of Sex Offender Registration”, Journal of Contemporary Criminal Justice, 21: 67-81.

Tewksbury, R. (2004) "Experiences and Attitudes of Registered Female Sex Offenders", Federal Probation, 68: 30-33.

Tewksbury, R. and J. Levenson (2009) "Stress Experiences of Family Members of Registered Sex Offenders", Behavioral Sciences and the Law, 27: 611-626. 
Travis, J. (2005) But They All Come Back: Facing the Challenges of Prisoner Reentry, Washington (D.C.): The Urban Institute.

Zandbergen, P. A., J. L. Levenson and T. C. Hart (2010) "Residential Proximity to Schools and Daycares: An Empirical Analysis of Sex Offense Recidivism", Criminal Justice and Behavior, 37: 482-502.

\section{ABOUT THE AUTHOR}

Brian E. Oliver, $\mathrm{PhD}$, is an ex-convict and member of the Convict Criminology Group. He received his $\mathrm{PhD}$ in Criminology and Criminal Justice from the University of Missouri-St. Louis in 2011. While in graduate school his course of study focused on several topics including intervention programming with at-risk individuals, collateral consequences faced by those with felony records, and the areas of recidivism and reentry. His work appears in Child Abuse \& Neglect, Trauma, Violence \& Abuse, Justice Research \& Policy and Dialectical Anthropology. His current research explores whether variations in cumulative individual level characteristics associated with recidivism can be used to explain differences in recidivism rates across American states. 